\title{
Pengaruh Aplikasi Bioflock yang Dikombinasikan dengan Probiotik Terhadap Performa Pertumbuhan Udang Vaname
}

\author{
(THE IMPACT OF BIOFLOCKS APPLICATION COMBINED WITH PROBIOTICS ON \\ THE GROWTH PERFORMANCE OF WHITELEG SHRIMP)
}

\section{Bagus Dwi Hari Setyono*, Fariq Azhar, Paryono}

\author{
Laboratorium Budidaya Perairan, Program Studi Budidaya Perairan, Universitas Mataram, \\ Jl. Pendidikan 37 Mataram Ph. 08179641776. \\ *Email: budidayaperairan@unram.ac.id
}

\begin{abstract}
ABSTRAK
Pada budidaya udang yang dilakukann secara intensif banyak ditemukan permasalahan penyakit yang disebabkan oleh bakteri, virus, ataupun adanya ko-infeksi. Salah satu penyakit yang disebabkan oleh virus dan sering menjadi masalah utama dalam sistem budidaya udang vaname adalah IMNV (Infectious Myonecrosis Virus). Teknologi bioflok adalah salah satu alternatif yang dapat dilakukan untuk mengatasi masalah limbah budidaya. Teknologi ini mampu memberi keuntungan lebih karena selain dapat menurunkan limbah nitrogen anorganik, juga dapat menyediakan pakan tambahan bagi ikan budidaya sehingga dapat meningkatkan pertumbuhan dan efisiensi pakan. Penambahan probiotik dalam bioflok diharapkan mampu meningkatkan performa pertumbuhan udang vaname. Penelitian ini bertujuan untuk mengevaluasi penggunaan bioflock yang dikombinasikan dengan probiotik terhadap performa pertumbuhan udang vaname (Litopenaeus vannamei). Penelitian ini dilakukan selama 5 bulan. Perlakuan yang diberikan yaitu penambahan probiotik komersil dalam media budidaya dengan sistem bioflok dan pakan pellet hasil fermentasi dengan berbagai probiotik komersil, yakni probiotik I + bioflok (1), probiotik II + bioflok (2), probiotik III + bioflok (3), kontrol positif (media budidaya bioflok tanpa penambahan probiotik komersil) (4), dan kontrol negatif (tanpa probiotik dan tanpa bioflok) (5). Hasil penelitian menunjukkan bahwa performa pertumbuhan terbaik diperoleh pada perlakuan 2 dengan nilai sintasan $80 \%$, nilai laju pertumbuhan harian 4,9 dan nilai rasio konversi pakan sebesar 1,41.
\end{abstract}

Kata kunci: Udang vaname; probiotik; bioflok

\begin{abstract}
Intensive shrimp farming often dealing with many disease problems such as bacteria, viruses, or the presence of co-infection. One of the diseases caused by viruses and considered as a major problem in the shrimp farming is IMNV (Infectious Myonecrosis Virus). Bioflok technology is one alternative to overcome the problem of cultivation waste. Instead of reducing inorganic nitrogen waste, bioflock also provide an additional feeds for aquaculture animals, resulted in the improvement of the growth and efficiency of . The addition of probiotics into bioflock system is also expected to improve the growth performance of white shrimp. This study was aimed to evaluate the use of bioflock combined with probiotics on their effect to the growth performance of white leg shrimp (Litopenaeus vannamei). This research was conducted for 5 months. The treatment provided by adding commercial probiotics in culture medium with bioflock system and fermented pellet with various commercial probiotics, ie probiotics I + bioflock (1), probiotics II + bioflock (2), probiotics III + bioflock (3), positive control (bioflock culture medium without the addition of commercial probiotics) (4), and negative control (without probiotics + without bioflock) (5). It can be concluded that the best results for growth performance was obtained on treatment 2 with $80 \%$ of survival rate, the value of daily growth rate of 4.9 and the value of feed conversion ratio of 1.41.
\end{abstract}

Keywords: White Shrimp; probiotics; bioflock 


\section{PENDAHULUAN}

Pada budidaya udang yang dilakukan secara intensif banyak ditemukan permasalahan penyakit seperti bakteri, virus, ataupun adanya ko-infeksi (TeixeiraLopes, 2011). Salah satu penyakit yang disebabkan oleh virus dan sering menjadi masalah utama dalam sistem budidaya udang vaname adalah IMNV (Infectious Myonecrosis Virus) (Poulos et al., 2006).

Penyakit yang disebabkan oleh IMNV dapat memicu terjadinya kematian pada udang hingga $70 \%$. IMNV menyebar ke Indonesia pada tahun 2006 (Senapin, 2007). Selain infeksi oleh virus di alam juga sering ditemukan infeksi oleh bakterial, Vibrio sp sering ditemukan sebagai infeksi sekunder pada udang (Liu and Chen, 2004). TeixeiraLopes (2011) melaporkan bahwa udang vaname dapat terinfeksi oleh 2 jenis virus berbeda yaitu Infectious Hypodermal and Hematopoietic Virus (IHHNV) dan IMNV secara alami.

Penanggulangan penyakit bakterial pada ikan biasanya dilakukan dengan pemberian antibiotik, penggunaan fitofarmaka, dan vaksin. Pemberian antibiotik secara terus menerus dapat berakibat terjadinya resistensi bakteri terhadap jenis antibiotik tersebut. Selain itu, efek samping pemberian antibiotik dapat meninggalkan residu yang nantinya akan membahayakan manusia dan lingkungan. Perlu dicari alternatif untuk meningkatkan kekebalan tubuh dan mencegah wabah penyakit pada hewan akuatik (Zhang et al., 2012). Teknologi bioflok adalah salah satu alternatif yang dapat dilakukan untuk mengatasi masalah limbah budidaya. Bahkan mampu memberi keuntungan lebih karena selain dapat menurunkan limbah nitrogen anorganik, juga dapat menyediakan pakan tambahan bagi ikan budidaya sehingga dapat meningkatkan pertumbuhan dan efisiensi pakan. Penambahan probiotik dalam bioflok juga diharapkan mampu meningkatkan performa pertumbuhan udang vaname.

Probiotik merupakan mikroba tambahan yang memberikan pengaruh menguntungkan bagi inangnya melalui peningkatan nilai nutrisi pakan dan memperbaiki respon inang terhadap penyakit serta meningkatkan kualitas lingkungan (Verschuere et al., 2000). Konsep probiotik diterapkan untuk memelihara dan menjaga kesehatan secara preventif melalui perbaikan keseimbangan mikroflora usus. Probiotik menekan pertumbuhan dan perkembangan mikroorganisme patogen di dalam usus. Penelitian tentang probiotik telah banyak dilakukan untuk peningkatan produksi akuakultur sebagai suplemen makanan, peningkatan resistensi terhadap penyakit, serta peningkatan kinerja pertumbuhan (Nayak, 2010). Selain itu, pemberian probiotik dalam kadar yang optimal juga mampu merangsang pertumbuhan dan perkembangan mikroorganisme sejenis yang menguntungkan (Aly et al., 2008). Probiotik juga mampu berperan sebagai imunostimulan, meningkatkan rasio konversi pakan, mempunyai daya hambat pertumbuhan bakteri patogen, menghasilkan antibiotik, serta peningkatan kualitas air (Watson et al., 2008).

Penelitian ini bertujuan untuk mengevaluasi penggunaan bioflock yang dikombinasikan dengan probiotik terhadap performa pertumbuhan udang vaname (Litopenaeus vannamei)

\section{METODE PENELITIAN}

\section{Lokasi dan Waktu Penelitian}

Lokasi penelitian dilaksanakan di laboratorium Budidaya Perairan, sedangkan analisis sampel dilaksankan di Laboratorium Bioekologi, Program Studi Budidaya Perairan, Universitas Mataram. Penelitian ini dilaksanakan selama lima bulan, dari bulan yaitu Mei-Oktober 2017).

\section{Persiapan Wadah dan Ikan Uji}

Udang vaname yang digunakan dalam penelitian ini adalah udang vaname berukuran $1.3 \pm 0.12 \mathrm{~g} / \mathrm{ekor}$ yang dipelihara dengan padat tebar 10 ekor/wadah. Sebelum diberi perlakuan, udang vaname terlebih dahulu dipelihara selama tujuh hari 
dalam akuarium untuk proses adaptasi. Wadah yang digunakan dalam penelitian berupa akuarium yang berukuran $40 \times 40 \times$ $40 \mathrm{~cm}$ yang diisi $20 \mathrm{~L}$ air dan dilengkapi dengan aerator, selang dan batu aerasi. Sumber air yang digunakan adalah air sumur, dengan tanpa pergantian air (zero water exchange).

\section{Persiapan Pakan Uji}

Pakan yang digunakan dalam penelitian ini adalah pakan pellet dengan kadar protein $45.77 \%$. Sebelum diberikan kepada udang, pakan difermentasikan terlebih dahulu dengan bakteri probiotik komersil yang berbeda sebanyak $2 \mathrm{ml} / \mathrm{kg}$ pakan, dengan dosis $10^{6} \mathrm{CFU} \mathrm{ml}{ }^{-1}$ selama dua hari. Pada perlakuan juga ditambahkan karbon berupa molase.

\section{Perlakuan}

Perlakuan yang diberikan yaitu dengan penambahan probiotik komersil dalam media budidaya dengan sistem bioflok dan pakan pellet hasil fermentasi dengan berbagai probiotik komersil, yakni probiotik I + bioflock (1), probiotik II + bioflock (2), probiotik III + bioflock (3), kontrol positif (media budidaya bioflok dan tanpa penambahan probiotik komersil) (4), dan kontrol negatif (tanpa probiotik + tanpa bioflok) (5).

\section{Analisis Data}

Data pertumbuhan spesifik, kelangsungan hidup (SR), rasio konversi pakan (FCR) dan kualitas air dianalisa secara statistik dengan one-way analysis of variance menggunakan software statistik SPSS (versi 18) pada selang kepercayaan 95\% ( $\mathrm{P}<0.05)$. Apabila terdapat perbedaan nyata, dilakukan uji lanjut Tukey.

\section{HASIL DAN PEMBAHASAN}

Parameter sintasan pada akhir pelakuan yang disajikan pada Gambar 1 menunjukkan bahwa terdapat pengaruh yang nyata terhadap nilai sintasan pada setiap perlakuan. Dimana sintasan tertinggi diperoleh pada perlakuan 2 (bioflok + probiotik II) sebesar $90 \%$ diikuti oleh perlakuan 1 (bioflok + probiotik I) $(80 \%)$, perlakuan 3 (bioflok + probiotik III) $(80 \%)$ dan perlakuan 4 (bioflok tanpa probiotik) (70\%), perlakuan 5 (serta tanpa bioflok + tanpa probiotik) (70\%).

Laju pertumbuhan harian (SGR) pada penelitian ini berbeda secara signifikan antar perlakuan dengan kontrol. Namun tidak berbeda nyata antar perlakuan. Nilai SGR tertinggi diperoleh dari perlakuan 2 $(4,9 \%)$, diikuti oleh perlakuan $1(4,2 \%)$; perlakuan 3 (4,1\%); kemudian sebesar $3,5 \%$ untuk perlakuan 4 dan 3,1\% untuk perlakuan 5 (Gambar 2).

Rasio konversi pakan (FCR) berbeda nyata antara perlakuan P1 dengan kedua kontrol. FCR terbaik diperoleh pada perlakuan 2 yaitu sebesar 1,41; kemudian diikuti oleh perlakuan 3 sebesar 1,53, perlakuan 1 sebesar 1,54; kemudian kedua perlakuan 4 yaitu sebesar 1,69 dan perlakuan 5 sebesar 1,70 (Gambar 3).

Bioflok merupakan campuran heterogen dari mikroorganisme, partikel, koloid, polimer organik, kation dan sel mati (De Schryver et al., 2008). Berdasarkan pengamatan yang dilakukan pada semua perlakuan bioflok, ditemukan beberapa mikroorganisme yang menjadi penyusun bioflok antara lain cacing, zooplankton, phytoplankton serta protozoa. Bakteri heterotrof merupakan salah satu pembentuk komunitas bioflock yang paling dominan selain fitoplankton, kumpulan bahan organik hidup dan mati dan pemakan bakteri (Hargreaves, 2006). Bacillus merupakan genus bakteri yang ditemukan pada semua perlakuan. Bakteri heterotrof akan tumbuh maksimal melalui peningkatan rasio $\mathrm{C} / \mathrm{N}$ dengan menambahkan sumber karbon organik secara kontinu seperti molase, tepung terigu dan tepung tapioka (Avnimelech, 1999). 
Sintasan

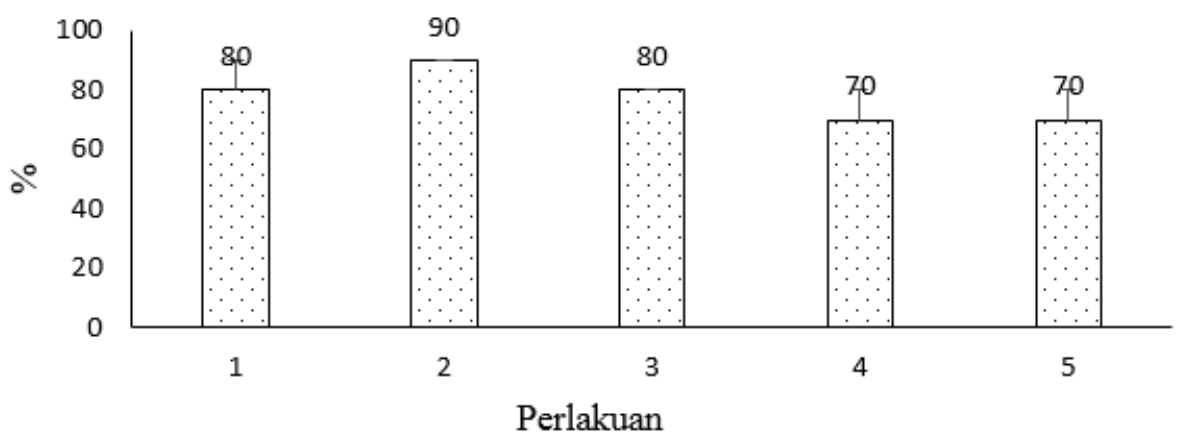

Gambar 1. Sintasan udang uji (Litopenaeus vannamei)

Laju Pertumbuhan Spesifik

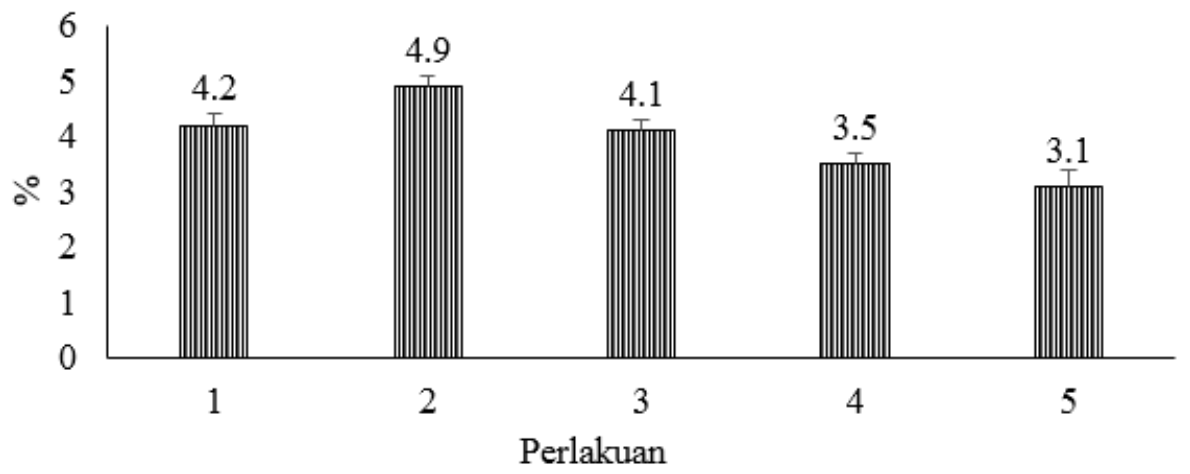

Gambar 2. Laju Pertumbuhan Harian udang uji (Litopenaeus vannamei)

Rasio Konversi Pakan

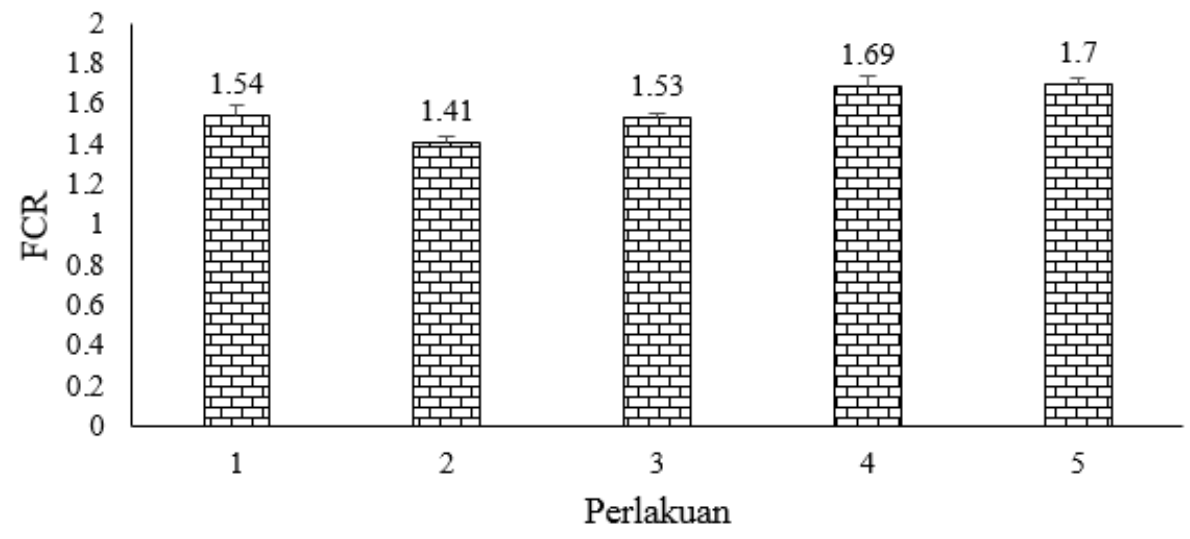

Gambar 4. Rasio Konversi Pakan udang uji (Litopenaeus vannamei)

Teknologi bioflok dapat dilakukan dengan menambahkan karbohidrat organik ke dalam media pemeliharaan untuk merangsang pertumbuhan bakteri heterotrof dan meningkatkan rasio $\mathrm{C} / \mathrm{N}$ (Crab et al., 2007). Molase merupakan gula sederhana sehingga dapat dengan mudah dimanfaatkan oleh koloni bakteri untuk mempercepat pertumbuhan. Kemampuan bakteri untuk dapat mengurangi nitrogen anorganik dalam lingkungan budidaya dan memproduksi protein mikrobial tergantung pada koefisien konversi mikroba, C/N rasio, biomassa bakteri, serta kandungan karbon dari bahan yang ditambahkan (Avnimelech, 1999).

Meningkatnya respon imun udang tersebut dapat mempengaruhi nilai sintasan 
menjadi lebih tinggi, karena resistensi udang terhadap patogen juga meningkat. Hal ini didukung dengan nilai sintasan udang pada perlakuan 2 yang lebih tinggi dan berbeda nyata dengan perlakuan 4 dan perlakuan 5. Selain itu, menurut De Schryver et al. (2008) bioflok mengandung poly- $\beta$-hydroxibutirat (PHB) yang dapat meningkatkan sistem imun. Probiotik Vibrio SKT-b yang ditambahkan dalam sistem bioflok juga mempengaruhi tingginya nilai sintasan, karena probiotik SKT-b (Vibrio alginolyticus) efektif menekan pertumbuhan Vibrio harveyi dengan cara kompetisi melalui tempat pelekatan atau sumber nutrisi (Widanarni et $a l .$, 2008). Poly- $\beta$-hydroxibutirat (PHB) merupakan polimer intraseluler yang dihasilkan oleh berbagai mikroorganisme yang berkaitan dengan sumber karbon dan penyimpanan energi yang dapat meningkatkan sistem imun. Kandungan PHB dalam bakteri dapat melindungi organisme akuatik dari serangan bakteri patogen. Partikel PHB terdegradasi menjadi $\beta$-hydroxibutirat dalam usus udang dan pembentukan asam lemak ini melindungi udang dengan dua cara yaitu, menyediakan energi untuk udang dan menghambat pertumbuhan dari patogen (De Schryver et al. 2008).

Konversi pakan perlakuan 5 lebih tinggi dengan semua perlakuan terutama dengan perlakuan 1, 2, dan 3. Burford et al. (2004) melaporkan bahwa hingga $29 \%$ dari asupan pakan harian Litopenaeus vannamei berasal dari bakteri alga/ bakteri flok yang berasal dari sistem budidaya heterotrof. Biomassa bakteri heterotrof dapat membentuk agregat (flok) bersama dengan mikroba lain, yang selanjutnya dapat dimanfaatkan oleh organime budidaya (De Schryver et al., 2008). Pada beberapa spesies lain yang dibudidayakan memberikan hasil dimana bioflok dapat digunakan sebagai sumber pakan alami yang memiliki kandungan protein 37-38\% (Azim and Little, 2008).
Umumnya udang yang diberikan pakan probiotik pada perlakuan 1,2 , dan 3 menunjukan performa yang lebih baik dibandingkan dengan perlakuan 4 dan perlakuan 5 selama 30 hari pemeliharaan. Performa pertumbuhan terbaik ditunjukan oleh perlakuan 2 dibandingkan dengan kontrol. Hal ini menunjukkan bahwa pemberian probiotik berpengaruh terhadap peningkatan performa pertumbuhan udang. Ai et al. (2011) melaporkan bahwa pemberian probiotik Bacillus subtilis dengan prebiotik fruktooligosakarida dapat meningkat SGR dan FER pada juvenil yellow croaker. Hal serupa juga telah dilaporkan oleh Daniels et al. (2010) bahwa pemberian Bacillus spp. dan mannanoligosakarida (MOS) pada lobster (Homarus gammarus L) dapat meningkatkan performa pertumbuhan lobster. Meningkatnya performa pertumbuhan udang mungkin disebabkan oleh meningkatkan aktivitas enzim pencernaan yang diinduksi oleh probiotik (Wang, 2007). Menurut Ai et al. (2011) bakteri pencernaan mengambil bagian dalam dekomposisi nutrisi, memberikan makroorganisme dengan bahan aktif secara fisiologis seperti enzim, asam amino dan vitamin, dengan demikian memfasilitasi pemanfaatan pakan dan pencernaan.

\section{SIMPULAN}

\section{Simpulan}

Teknologi bioflok dan probiotik dapat meningkatkan kinerja performa pertumbuhan udang melalui peningkatan nilai sintasan, rasio konversi pakan dan laju pertumbuhan spesifik terbaik diperoleh pada perlakuan 2 (bioflok + probiotik 2) dengan hasil masing-masing $80 \%, 1,4$ dan $4,9 \%$.

\section{Saran}

Perlu dilakukan penelitian lanjutan tentang sistem imun udang untuk mengetahui efektifitas penggunaan bioflok yang dikombinasikan dengan probiotik. 


\section{UCAPAN TERIMA KASIH}

Penulis mengucapkan terima kasih kepada Lembaga Penelitian dan Pengabdian kepada Masyarakat Universitas Mataram.

\section{DAFTAR PUSTAKA}

Ai Q, Xu H, Mai K, Xu W, Wang J, Zhang W. 2011. Effects of dietary supplementation of Bacillus subtilis and fructooligosaccharide on growth performance, survival, non-specific immune response and disease resistance of juvenile large yellow croaker, Larimichthys crocea. Aquaculture. 317 : 155-161.

Aly SM, Mohamed MF, John G. 2008. Effect of probiotics on the survival, growth and challenge infection in Tilapia nilotica (Oreochromis niloticus). Aquaculture Res. 39: 647656.

Avnimelech Y. 1999. Carbon/nitrogen ratio as a control element in aquaculture system. Aquaculture. 176: 227-235.

Azim ME, Little DC. 2008. The biofloc technology (BFT) in indoor tanks: water quality, biofloc composition, and growth and welfare of Nile tilapia(Oreochromis niloticus). Aquaculture. 283: 29-35.

Burford MA, Thompson PJ, McIntosh RP, Bauman RH, Pearson DC, 2004. Nutrient and microbial dynamics in high intensity, zero-exchange shrimp ponds in Belize. Aquaculture. 219: 393411.

Crab, R., Y. Avnimelech, T. Defoirdt, P. Bossier, and W. Verstraete. 2007. Nitrogen Removal Techniques in Aquaculture for Sustainable Production. Aquaculture. 270: 1-14.

Daniels CL, Merrifield DL, Boothroyd DP, Davies SJ, Factor JR, Arnold KE. 2010. Effect of Dietary Bacillus spp. and Mannan Ologosaccharides (MOS) on European Lobster (Homarus gammarus L) Larvae Growth Performance, Gut Morphology and Gut Microbiota. Aquaculture. 304: 49-57.
De Schryver P, Carb R, Derfoirth P, Boon N, Verstrete W. 2008. The basics of bio-flocs technology: The added value for aquaculture. Aquaculture. 277: 125137.

Hargreaves JA. 2006. Photosynthetic suspended-growth systems in aquaculture. Aquac. Eng. 34: 344-363.

Liu CH, Chen CJ. 2004. Effect of ammonia on the immune response of white shrimp Litopenaeus vannamei and its susceptibility to Vibrio alginolyticus. Fish and Shellfish Immunol. 16: 321334.

Nayak SK. 2010. Probiotics and Immunity: A Fish Perspective. Review. Fish and Shellfish Immunol. 29: 2-14.

Poulos BT, Tang KFJ, Pantoja CR, Bonami JR, Lightner DV. 2006. Purification and characterization of infectious myonecrosis virus of penaeid shrimp. $J$. Gen. Virol. 87: 987-996.

Senapin S, Phewsaiya K, Briggs M, Flegel TW. 2007. Outbreaks of infectious myonecrosis virus (IMNV) in Indonesia confirmed by genome sequencing and use of an alternative RT-PCR detection method. Aquaculture. 266: 32-38.

Teixeira-Lopes MA, Vieira-Girão PRN, da Cruz Freire JE, Rocha ÍRCB, Costa FHF, Rádis-Baptista G. 2011. Natural Co-infection With Infectious Hypodermal and Hematopoietic Necrosis Virus and Infectious Myonecrosis Virus in Litopenaeus vannamei in Brazil. Aquaculture. 312: 212-216.

Verschuere L, Rombaut G, Sorgeloos P, Verstraete W. 2000. Probiotic Bacteria as Biological Control Agents in Aquaculture. Microbiol. Mol. Biol. Rev. 64(4): 655-671.

Wang YB. 2007. Effect of Probiotics on Growth Performance and Digestive Enzyme Activity of The Shrimp Penaeus vannamei. Aquaculture. 269: 259-264.

Watson AK, Kaspar H, Lategan MJ, Gibson L. 2008. Probiotics in aquaculture: The need, principles and mechanisms of 
action and screening processes. Aquaculture. 274: 1-14.

Widanarni, Sukenda, Setiawati M. 2008. Bakteri Probiotik dalam Budidaya Udang: Seleksi, Mekanisme Aksi, Karakterisasi dan Aplikasinya Sebagai Agen Biokontrol. J. Ilmu Pertanian Indonesia. 13(2): 80-89.
Zhang J, Liu Y, Tian L, Yang H, Liang G, Xu D. 2012. Effects of Dietary Mannan Oligosaccharide on Growth Performance, Gut Morphology and Stress Tolerance of Juvenile Pacific White Shrimp Litopenaeus vannamei. Short Communication. Fish and Shellfish Immunol. 33(4): 1027-1032. 